\title{
Forum
}

\section{A peripatetic model for teaching Latin}

\author{
Clare Harvey
}

Key words: Latin, teaching, peripatetic, examinations

This article explores a model of teaching Latin at several statefunded secondary schools within the same geographical location. This model could work for Latin teachers who wish to reintroduce Latin to parts of the country where there are few ready-made jobs in Classics teaching. It will work best in an area where there are a number of secondary schools within easy travelling distance of one another.

\section{Introduction}

I was a mature student when I began teaching in 2013. In 2016, after having completed first the Cambridge PGCE in Classics then two years part-time in a state grammar school in order to gain my qualified teacher status, I approached several headteachers in the town where I live, just north of London. My intention was to take Latin to some schools which did not currently offer it and to piece together a substantial job while working in the state sector. This was something I had wanted to do ever since my own children had wished that Latin was on offer in the comprehensive school that they attended.

Initially three (and later four) schools agreed to work with me.

The schools:

SS - A semi-selective (1/3 selective) mixed-sex secondary

MF - A mixed-sex comprehensive academy school

F - A girls-only comprehensive academy school

$\mathrm{M}$ - A boys-only comprehensive academy school

At the first three schools (SS, MF \& F) I offered one and a half hours of lessons at the end of a school day once a week for 30 weeks of the year (10 weeks per term). All schools wanted the class to lead to a GCSE.

I was also asked to include a fourth school (M) where I would teach for 40 minutes in the lunch hour. This was a school where another freelance teacher was already covering Latin, but in this particular academic year, she had no capacity to start a new cohort.

To whom was it offered?

SS offered Latin to years $7,8 \& 9$ resulting in 21 pupils

MF offered Latin to years $8,9 \& 10$ resulting in 22 pupils

Author of correspondence: Clare Harvey, E-mail: clarefharvey@hotmail.com

Cite this article: Harvey C, (2020). A peripatetic model for teaching Latin. The Journal of Classics Teaching 21, 86-87. https://doi.org/10.1017/S2058631020000069

\author{
F offered Latin to years $8 \& 9$ \\ M offered Latin to years $8 \& 9$ \\ Total: 61 pupils.
}

resulting in 9 pupils

resulting in 9 pupils

I also teach Latin evening classes for two different local providers of adult education. This includes some of the parents of my school pupils and is rewarding for me and helps to develop the local Classics community.

\section{Relationship with the Schools}

The schools were keen to offer Latin as it was seen to be valued by parents. 'Do you offer Latin?' was a question often asked by parents at the annual open evening for Year 6 pupils. Head teachers also saw Latin as boosting literacy, linguistic ability and cultural knowledge.

Due to strained budgets, none of the schools I approached was able to pay me without passing on the charges to the parents. A couple of schools chose to take the fees from the parents themselves and pay me an hourly rate, while the other two insisted that I collect the fees from the parents myself. The second option turned out to be preferable as, over the three years, this gave me a higher average income.

\section{Lesson Routine}

I committed to follow the popular and well-supported Cambridge Latin Course.

- 'Soft start' with a starter handout designed to 'get their Latin heads on' and prepare pupils for the week's test.

- Register.

- Test on last week's homework - vocabulary or accidence.

- Starter sentences and/or story - new language point.

- 'God of the Week' - the (very popular) mythology spot.

- Roman Civilisation topic - they find this intrinsically interesting and it is easy to catch up on for anybody who has to leave early.

- Since I am dealing with pupils of 2-3 different year groups, extension tasks are always offered and promoted.

\section{After the Lesson}

Each week, I email out to all parents the PowerPoint used in class for pupils to catch-up if necessary and so they have a copy of the homework. 
I also email parents of any pupils who have unexplained absences so everybody comes to understand attendance is important.

\section{Equipment}

Because of the benefit to the school of being able to offer Latin as an extra subject, the schools were willing to supply free of charge a classroom, computer log-in for me as teacher, exercise books and exam entry. The Roman Society kindly gave a grant for the provision of text books.

\section{Exams}

The provision of an exam qualification provided the greatest point of difficulty. Head teachers and most parents wanted the classes to lead to a GCSE in Latin. However, it is difficult to keep a viable extra-curricular class together for more than three years. 1.5 hours a week was a good lesson length. However, it was not as productive as I had hoped for the following reasons:

- Because each class was composed of two or three year-groups, there were two or three times the usual number of disruptions due to trips, exams and so on.

- The pupils were already tired when they reached me at the end of the school day.

- I saw pupils only one day a week, which meant they were activating brain pathways only once a week, especially if they left homework to the last minute.

When I assessed pupils at the end of their second year it looked as if they would have to work very hard in their final year to get good grades at GCSE. Since Latin was already an extra subject, this did not bode well. Therefore, after much consultation with teachers and parents, I decided to ask the schools to enter the pupils for the WJEC Level 2 certificate in Latin Language and Roman Civilisation instead of GCSE. This avoided the labour-intensive literature paper.

This change of plan, midway through the course, caused some consternation and several pupils left. However, the outcome was that the majority of remaining pupils gained a Level 2 Certificate result that they could take pride in rather than a GCSE result that they might wish to conceal.

Unfortunately, when my new cohort of pupils reach their external exams in 2022, the WJEC Level 2 certificate will no longer be on offer, so they will be forced to take the GCSE. My plan is to supplement the regular classes with several Saturday morning workshops and to flag this up to parents well in advance.

\section{Results}

Of the 32 pupils who took the WJEC Level 2 certificate in Latin Language and Roman Civilisation the results were as follows:
A ${ }^{\star} 17$ pupils
A 10 pupils
B 3
C 1
$\mathrm{U} \quad 1-\mathrm{U}$ is anything below $\mathrm{C}$ in this qualification; there is no $\mathrm{D}, \mathrm{E}, \mathrm{F}$.

Five pupils across three schools were eager to continue with Latin (something I had not anticipated) and now attend an AS Latin class in my home.

\section{The problem of shrinkage}

Drop-out is inevitable over the course of three years. This was often because children (and parents) who volunteer for this kind of financial and time commitment are also committed elsewhere. Amongst my pupils I had a fencing champion, a county rugby player and a performing singer (all of whom actually finished the course). I made it a policy always to be positive and encouraging when a child gave up Latin because they felt over-stretched. After all, their welfare is paramount.

Modes of payment also had an effect on the drop-out rate. Two schools wanted parents to be billed each term, giving pupils three opportunities each year to drop out. The other two demanded payment in advance for the whole year which fostered more commitment right from the start. Therefore, collecting a year's payment in advance is preferable, also meaning that the cycle of billing and chasing late-payers only happens once in the year (I do however allow payment by installments to parents where there is a need).

The other main causes were increased workload and less fun in the second year as we began working towards public exams and also the point at which I switched the destination exam from GCSE to Level 2 Certificate (see above).

I maintained income as the school classes became smaller by offering additional adult classes and also lunch-time clubs for younger school children.

I also combined the small classes of schools $\mathrm{M}$ and $\mathrm{F}$ and taught them both at school F, thus creating one viable class and freeing up one of my time slots.

\section{Adjustments to the original modus operandi}

I now split each 90-minute lesson with a ten-minute break. It helps refresh tired pupils and gives them a chance to bond with one another - they come from many different form groups. It also allows me time with individuals who want to show me something or who have missed a lesson.

Rather than sticking to ten sessions each term, I am now completing as many sessions as possible during the first two terms to allow leeway for teacher illness or family emergencies. It is also a good idea to schedule as little important work as possible for the second half of the summer term when trips and concerts are prevalent.

\section{Conclusion}

Ideally, Latin would be offered to pupils free of charge. However, this is often not possible given the state of school budgets and the demands already being made on permanent staff.

However, the model I have developed allows pupils to access Latin at a very much lower cost than if paying for private lessons outside school and has seen Latin started/reintroduced in three state schools where it was not previously available.

I have started a new cohort in each of my three main schools and, due to the success of the first cohort, have attracted a larger number of pupils this time round, including a number of younger siblings. 